\title{
Editorial
}

\section{How large is the world of global constitutionalism?}

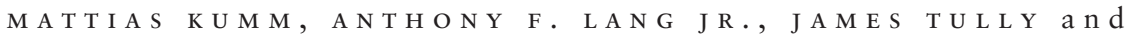
A N T J E W IE NER

As Global Constitutionalism enters its third year, we want to take the opportunity to reflect on and explore the conceptual and institutional boundaries of the world of global constitutionalism. In our first editorial two years ago we defined the mission of the journal to promote a deeper understanding of the foundations, limitations and principles of political order and their dynamics over time across or between states, institutions or political communities. We insisted that Constitutionalism is not to be understood primarily as the study and interpretation of a constitutive legal document, but as a reference frame for interdisciplinary research with a particular focus. We elaborated on the challenges of interdisciplinarity in our second editorial. In this year's editorial we want to reflect further on the particular focus that comes with a constitutionalist frame of reference.

\section{The focus of constitutionalism: Constitutive principles of legitimate authority and constituent power}

The particular focus of constitutionalism, we have always insisted, is provided by its engagement with basic norms constitutive of legitimate authority which validate posited law, including law posited by acts of constituent power, both within and beyond the state. The constitutional register is the most fundamental political and legal way to contest and justify legal and political claims. Ordinary political contestation and disagreement concern questions whether this or that policy is good or bad, whether it is just or unjust, legal or illegal (compliance with ordinary posited law). This is the domain over which we must reasonably expect to have disagreement and over which public authorities rightly claim legitimate authority to settle things. Shifting to the constitutional register means contesting or justifying issues in terms of legitimate authority, not merely good or bad policy, justice or injustice, legality or illegality. 
To take an example from the US revolutionary context: It is one thing to criticize a tax, like the British tax imposed on tea, on the grounds that it is bad policy or arguably unjust. It is another to challenge it as violating constitutive principles and falling outside of the scope of legitimate public authority. Resistance to the tax was justified by reference to the principle of 'no taxation without representation', derived from a more general principle of democracy. That principle was taken to be a principle constitutive of legitimate public authority by those that resisted the tax in Massachusetts (even if it was not recognized as such by the Westminster Parliament).

Similarly, when public authorities use the constitutional register, as paradigmatically constitutional courts do when they assess acts of public authorities, they do not pass on the justness or political desirability of the action or the ordinary legality of the action, with the latter often left to be decided by non-constitutional courts. Constitutional courts merely assess whether the acts are justifiable in light of the constitutional norms recognized as playing a constitutive role for the establishment and exercise of public authority. Note how even courts in domestic settings do not necessarily rely on a written constitutional text to justify their constitutional role. In some jurisdictions there is no formal constitutional text at all, yet there is constitutional review of legislation. In other contexts, where there are formal constitutions, courts have claimed the authority to assess amendments to the formal constitutional text in light of unwritten and unamendable constitutional principles and strike the former down as unconstitutional, if the latter are violated. Finally courts have also been known to play a role as guardians of constitutional principle as part of the constitution-giving process, that is, without a formal constitution in existence that provides a 'source' for their adjudicative practice. Whether or not it is appropriate for courts to play such a role is itself a question of constitutional principle and remains contested. In practice it depends on how courts interpret the constitutive principles with regard to their role in relation to other public authorities.

The Kadi case, already featured in our first editorial, is an example of constitutionalism in action in a transnational setting. It concerned the European Court of Justice striking down an EU Regulation that implemented a UN Sanctions regime based on a UN Security Resolution on the grounds that such enforcement would constitute a clear and obvious violation of human rights. Whereas the EU might generally be bound by UN Law - it is bound to recognize its legitimate authority to make determinations in the domain relating to international peace and security under Charter VII of the UN Charter, irrespective of whether it conforms to EU policy preferences or contestable justice claims - it does not have the authority to implement UN Law, where such enforcement would amount to clear and obvious 
violations of a human right. Such a violation, the court might have said, amounts to a violation of a constitutive principle that grounds and limits public authority, both the authority of the UN to bind Member States acting collectively within the framework of the EU and the authority of the EU to impose on individuals within its jurisdiction.

These examples conceptually clarify the kind of phenomena and issues in which Global Constitutionalism is and is not interested. This is not a general journal on law, either domestic or international, nor a general journal on international relations or comparative politics, nor is it a journal on political philosophy. The journal is focused on norms, actors, procedures and institutions implicating questions relating to the establishment and exercise of legitimate public authority across jurisdictions. Contributors to Global Constitutionalism tend to ask analytical, empirical or moral questions about these norms and the way they shape legal and political practice. They may ask how these norms should be understood and how they relate to one another. They may critically analyse how and why such norms are referenced, specified, interpreted, contested, rejected or ignored in particular legal and political practices and to what effect. Or they may seek to assess existing features of legal and political practice in light of a particular argued for understanding of these norms. The published articles in the previous three years bear testimony to the fact that political scientists, sociologists, anthropologists, lawyers and philosophers all have their contributions to make to the constitutionalist enterprise.

\section{A Global Constitutionalist Trinity? Human rights, democracy and the rule of law}

The publication record over the first couple of years also reflects the fact that constitutive and fundamental norms that implicate questions of legitimate authority generally include a commitment to human rights, democracy and the rule of law. The commitment to human rights, democracy and the rule of law - the trinitarian mantra of the constitutionalist faith (Kumm 2011) - is part of the deep grammar of the modern constitutionalist tradition. It provides an abstract template of principles in light of which concrete arrangements are negotiated and policies are forged in contemporary constitutionalist settings. Within this constitutionalist framework, wherever political and legal authority is constituted or exercised, it can be criticized or justified with reference to these concepts.

The meaning of each of these concepts and the nature of their relationship is contested, as are the institutional and policy prescriptions derived from such a commitment. That is why these commitments are typically given more concrete shape in legal documents such as constitutions of states, 
constitutional charters of international organizations, programmes of political parties, NGO charters, corporate codes of conduct, etc. But even when these concepts are worked out in more detail in legal documents, their authority may be contested and depends in part on whether they are believed to provide an adequate institutionalization of or respect for these principles. Closure and settlement will often only be reached if and to the extent constituents believe that they persuasively institutionalize these principles. Even then the document itself will be interpreted in light of the underlying principles as its implications are fleshed out in concrete struggles. The commitment to human rights, democracy and the rule of law, including the practices of contestation in and over them, provides an abstract template in light of which concrete arrangements are negotiated and policies are forged between individuals, groups, political communities or public authorities. Wherever political and legal authority is constituted or exercised, it is likely to be criticized or justified with reference to these three concepts.

The 'legitimatory trinity' as a central feature of a modern constitutional discourse came into the world with the French and American Revolutions, and was internally connected to ideas of individual and collective selfgovernment at the time. It went through various challenges and permutations before it re-emerged after World War II to become a globally hegemonic discourse since the 1990s, both in and beyond the state. There is no liberal constitution enacted after 1990 that does not pledge allegiance to the trinity in some way. The European Union asserts that these are its foundational values, the Council of Europe has embraced it, the UN claims to be committed to it and various General Assembly Resolutions have endorsed it. In global public discourse this is the language most likely to be used and most likely to be effective when either contesting or resisting authority or using it to justify the imposition of restrictions on others.

The link between the name of the journal picks up on the contested nature of the trinity, inviting innovative contributions in critical reflection of conventional approaches to modern constitutionalism. The three conceptual pillars of global constitutionalism are represented by the three colourful somewhat uneven broad strokes with rough edges that structure the cover of the journal. They nicely symbolize the pluralist nature and contested contours of constitutional practice.

\section{Beyond the Constitutionalist Trinity: Power and other grounds}

Of course political authority is also criticized and justified on other grounds. Invocations of the inspired will of the Fübrer, Duce or Caudillo to justify authority may have been consigned to the dustbin of history. Claims of a leftist 'Great Leader' or Líder Máximo, too, hardly resonate outside of 
localized contexts that are few and far between. Even avant-garde parties in the Marxist-Leninist tradition monopolizing political life, such as the Chinese Communist Party, only survive by virtue of abandoning all central tenets of that tradition in order to focus on economic development and creating a growing middle class of consumers. There are two reasons why the historically triumphalist claims relating to 'the end of history' (Fukuyama's claim was not triumphalist and more complex) are nonetheless misguided.

First, the world of the political is not confined to processes of contestations in which claim-making and justification are a central feature. There remains more than enough space for old-fashioned unadorned power politics, power-mongering or war-lordism both within and beyond the state. Power in this sense refers to an attitude that connects authority with threats and nothing more. If challenged to provide justifications its response is: 'Because we can. What are you going to do about it?' What limits it and moves it to negotiate is counter-power. Not infrequently strongmen and despots seek validation by investing in constitutionalist gestures, thereby implicitly acknowledging the legitimating normative power of constitutionalism. They may invest in a sham constitution-giving process or ratify a human rights treaty, without the slightest intention of adapting their behaviour to comply with these norms. But when, to take up a current issue, China insists that certain rocks and islands in the East and South China Sea are rightly theirs, refuses to participate in legal proceedings to help settle these claims notwithstanding legal obligations under the UN Law of the Sea Convention, and unilaterally expands its air defence zone, 'realist' frames of reference appear more illuminating to understand what is going on than any constitutionalist analysis. From the perspective of Global Constitutionalism here the only questions raised are either empirical - what accounts for the absence of constitutionalist practices in certain domains, but not in others - and, normative - what might help bring about a normatively more desirable state of affairs. In a different context that is also focused on China and reflects a similar tension between any plausible interpretation of constitutionalist norms and national practice, Ge Chen in this volume analyses the effects of the fragmented international human rights regime on China's censorship policies, and comes to a surprisingly optimistic conclusion.

Second, in many places and contexts political and legal authority continues to be at least partially justified and challenged with reference to norms of state sovereignty, national identity, national will, ethnic or tribal traditions, or divine imperatives. Constitutionalist justification and contestation structured around the trinitarian formula, then, is not universal and has no monopoly. But it is global and not geographically limited. In particular it 
is not confined to 'the West'. It is a forceful presence in all six inhabited continents. And it is, for better of for worse, part of a hegemonic discourse on the conditions of legitimate political authority and political reform in the state and beyond the state. Norms connected to human rights, democracy and the rule of law have provided a powerful language of critique and contestation used by those oppressed, exploited and discriminated against seeking to articulate their demands and improve their situation. But it is also a language of power. A constitution can 'empower' a people through the creation of new institutions by which interests and powers can be channelled to productive outcomes. But those who exercise powers in the name of the people then make reference to the constitution in order to justify the demands and burdens they place on others. Whether 'enhanced interrogation techniques' formerly known as torture, drone strikes or the development of Orwellian intelligence supervisory practices, the US and European response to security threats emanating from organized criminals bent on violence for political reasons have not only been challenged, but also justified in constitutionalist terms.

Constitutionalism provides a vocabulary that has a hold on the world - it is able to connect to the inside of institutions, procedures, practices and self-understandings that are central to the legal and political world we live in. It does not impose an abstract ideal on political and legal practices, but brings to light and makes explicit the normative structure of that practice, while nonetheless also providing critical standards for assessing it. Legal and political practices are to a large extent already structured by constitutional norms and yet are simultaneously susceptible to being criticized by them.

\section{Global Constitutionalism and the sovereign state}

As the articles published between these covers in the past years have testified, and as our first editorial made clear, the journal is a large tent for a wide range of methodological approaches and subject-matter orientations. It is not committed to a particular conception of constitutionalism. It is certainly not committed to a global constitutional state. It is, of course, open for contributions such as that by William Scheuerman in this issue, stressing the virtues of a robust political and institutional cosmopolitanism in addition to the contestatory practices that are captured by the range of pluralist constitutionalist contributions. Not surprisingly, therefore, Global Constitutionalism is difficult to reconcile with the kind of sovereignty and state-focused conception of public law that Martin Loughlin has championed against theories of 'constitutional pluralism' in his contribution to this issue. We will leave it to readers to judge whether the particular critique of 'constitutional pluralism' he engages in is successful or not. 
But Loughlin also helpfully provides an analytically sharp description of what he calls 'the modern positivist edifice of public law'. What he means by that is a traditional statist and sovereigntist conception of public law, that was historically influential (although always contested), and remains influential in some jurisdictions today. As Loughlin presents it, sovereignty is the name given to the supreme will of the state; statehood and sovereignty express principles of unity and closure and signify ultimate authority. The sovereign state is the source of all law. This is a conception, which in different permutations and variations can be traced from Bodin to Hobbes, from Austin to Jellinek and to Schmitt. Because Loughlin might be right to implicitly characterize much of what Global Constitutionalism stands for as a full-fronted assault on the conceptual edifice of sovereigntist statism, it appears apropos to recapitulate briefly some of the considerable explanatory and normative difficulties of this conception.

Explanatorily the monopolization of all sources of law in the will of the sovereign leads to constructive contortions, not only with regard to international law, but also national customary and local law. In international relations theory 'realists' tried to resurrect scepticism about international law in the twentieth century by questioning its efficacy and thus providing support for sovereigntist conceptions of law, but these sceptical accounts are largely deemed to have failed - exactly because they are not able to provide an account that explains the actual patterns of compliance with international law - and are largely peripheral to the discipline today. Within the positivist camp the attacks on statist, sovereigntist conceptions of public law by authors like HLA Hart or Hans Kelsen are widely believed to have been successful. Norms are the foundations of law, not the 'the will of the sovereign state'.

Normatively it is questionable what might justify monopolizing the state as the source of law and attributing ultimate authority to it. Of course nationalist ideas dovetail nicely, endowing 'we the people' - the demos of a nation state - with unlimited authority. This gave a conceptual structure connected to seventeenth-century absolutist monarchism a second lease on life, founding a sovereign statist strand within the modern constitutional tradition. Furthermore, statist modern constitutional theorists have the tendency to emphasize the virtues of national democratic processes over every other kind of process to justify this understanding of the state's constitutional authority. But of course none of this is plausible. Local democratic processes matter too and so do the externalities that state policies inflict on outsiders. That is why sub-state law and international law limit the claims of legitimate authority that a state can plausibly make. The often repeated normative argument in favour of sovereigntism - the need to have an ultimate decider - has never been plausible. If this really 
were the one concern to trump all others, then only a global state could possibly be a solution to the problem. But, of course, it isn't. Besides, in modern constitutional systems the very idea of an ultimate decision is problematic in light of the possibility to revise politically whatever decision has just been affirmed by the final authority (e.g. a constitutional court).

Not surprisingly, throughout its history the statist sovereigntist conception of law has again and again been challenged as particular kind of formal conceptualist legal ideology, one that fails to be able to give a proper account of itself either in normative or empirical terms. The very fact of deep disagreement on the foundations of public law, including disagreement on the role and function of the state within it, suggests that public law is significantly more robust than statist theories are inclined to believe. In this way the world of public law theorizing bears resemblance to the world of public law generally; a world where conflicts are channelled through particular conceptual structures and institutions, but always connected to and suffused by policy considerations, the ideology of the day and often enough subject to considerable contestation and deep disagreement. Global Constitutionalism, as it is featured in scholarly pursuits in these pages, may reflect a wide range of conceptions of public law. It certainly encourages scholarly debates about the merits of competing conceptions. It invites even sharp criticism, such as Loughlin's contribution and this response to it. Such critical dialogue brings to light the deeper questions and transformations raised by processes of global constitutionalism.

Finally the editors would like to thank CUP for the support in establishing and running the journal successfully. We would like to thank especially Patrick McCartan, Jim Ansell, Duncan Yardy, David Vaughan, Julia Hochbach, Richard Horley and Holly Buttimore.

\section{Reference}

Kumm, Mattias. 2011. “An Integrative Theory of Global Public Law: Cosmopolitan, Pluralist, Public Reason oriented" available at <http://www.ucl.ac.uk/laws/jurisprudence/docs/ 2011/2011_kumm.pdf> accessed 31 December 2013. 